\title{
Differences in stroke patterns and outcomes between cancer and non-cancer patients
}

\author{
Bernardo Cacho-Díaz ${ }^{*}$, Héctor Spínola-Maroño ${ }^{1}$, Laura G. Mendoza-Olivas ${ }^{1}$, Karen Salmerón-Moreno ${ }^{1}$, \\ Alejandro Monroy-Sosa ${ }^{1}$, Carlos Cantú-Brito ${ }^{2}$, and Myrna G. Candelaria-Hernández ${ }^{3}$ \\ ${ }^{1}$ Neuro-Oncology Unit, Instituto Nacional de Cancerología; ${ }^{2}$ Department of Neurology and Psychiatry, Instituto Nacional de Ciencias Médicas y \\ Nutrición Salvador Zubirán; ${ }^{3}$ Research Unit, Instituto Nacional de Cancerología, Mexico City, Mexico
}

\begin{abstract}
Introduction: One in 10 patients with stroke concurrently has cancer; however, the impact of their combination on survival has not been well established; consequently, stroke and cancer are likely to have unrecognized associations. Objective: The objective of the study was to compare the stroke risk factors, presentations, and outcomes between stroke patients with and without cancer, to recognize this as an added hazard element that might impact mortality rates. Methods: Data were prospectively acquired at a cancer referral center from March 2011 to February 2018. Patients with histologically confirmed diagnosis of cancer, who were sent for neuro-oncology consultation and showed evidence by MRI of suffering a stroke during follow-up were compared with a previously reported cohort of patients with stroke and similar demographic characteristics (RENAMEVASC and PREMIER studies), employing Student's t-test after determining the mean and standard deviation using Hazen's equation. Results: A total of 270 patients with cancer-related stroke were compared to 2000 patients with non-cancer stroke. Stroke risk factors for the cohort of patients with cancer were dyslipidemia, alcohol abuse, and tobacco use, with a median follow-up after the stroke of 13.8 months. Mortality rates at 30 and 90-days were similar between both groups; however, at 6 and 12-months they were higher in patients with cancer-related stroke (6 months: 37 vs. $23 \%, R R$ 1.62, $p<0.0001$; 12 months: 43 vs. 29\%, RR 1.48, $p=0.00001)$. Conclusion: Mid-term and long-term survival rates were worse in cancer patients with stroke compared with those without cancer.
\end{abstract}

Key words: Cancer. Stroke. Survival. Mortality rates.

\section{Diferencias y desenlaces acorde al patrón de presentación de eventos vasculares cerebrales (EVC) en pacientes con cáncer y sin cáncer}

\section{Resumen}

Introducción: Uno de cada 10 pacientes que sufre un EVC tiene algún tipo de cáncer concomitante, sin embargo, el impacto de esta combinación no ha sido bien establecido. En consecuencia, es probable que el EVC y el cáncer presenten asocia-

\section{Correspondence:}

*Bernardo Cacho-Díaz

Neuro-oncology Unit

Instituto Nacional de Cancerología Date of reception: 12-06-2019

Mexico City, Mexico

Date of reception: 12-06-2019

Available online: $03-02-2020$

E-mail: bernardocacho@doctor.com

DOI: 10.24875/RMN.19000102

Rev Mex Neuroci. 2020;21(1):3-8

www.revmexneurociencia.com

1665-5044/@ 2019. Academia Mexicana de Neurología A.C. Published by Permanyer. This is an open access article under the CC BY-NC-ND license (http://creativecommons.org/licenses/by-nc-nd/4.0/). 
ciones no reconocidas. Objetivo: Comparar factores de riesgo, formas de presentación y desenlace en pacientes con cáncer y sin cáncer que sufrieron EVC, en función de reconocerlo como elemento adicional de riesgo que puede impactar sobre las tasas de mortalidad. Métodos: Se recopilaron datos prospectivamente en un centro de referencia oncológico desde marzo 2011 a febrero 2018. Pacientes con diagnóstico de cáncer confirmado por histopatología que fueron enviados a consulta de neuro-oncología y evidenciaron por medio de IRM algún tipo de EVC durante el seguimiento, se compararon contra una cohorte previamente reportada de pacientes con EVC sin relación a cáncer y características demográficas similares (estudios RENAMEVASC y PREMIER), empleando $t$ de Student después de determinar la media y la desviación estándar con la ecuación de Hozo. Resultados: Se comparó un total de 270 pacientes con EVC relacionado a cáncer contra 2,000 pacientes con EVC. Los factores de riesgo de EVC para la cohorte de pacientes con cáncer fueron dislipidemia, abuso de alcohol y uso de tabaco, con una mediana de seguimiento de 13.8 meses después del EVC. La tasa de mortalidad a 30 y 90 días fue similar en ambos grupos; sin embargo, a 6 y 12 meses fue mayor en el grupo de EVC relacionado a cáncer (6 meses: $37 \%$ vs. 23\%, RR 1.62, $p<0.0001$; 12 meses: $43 \%$ vs. 29\%, RR 1.48, $p=0.00001$ ). Conclusión: A mediano y largo plazo las tasas de supervivencia empeoraron en pacientes con EVC relacionado a cáncer.

Palabras clave: Cáncer. Evento vascular cerebral. Supervivencia. Tasa de supervivencia.

\section{Introduction}

In recent years, deaths related to stroke, the third most common cause of mortality worldwide ${ }^{1}$, have increased by $26 \%$, whereas the number of stroke survivors has increased by $84 \%$; there are slightly more than 33 million people who are currently living after stroke ${ }^{2}$. Conversely, cancer is the second most common cause of death, which has shown an increasing trend between 2005 and 2015 , with a $17 \%$ rise in the number of cancer-related deaths globally ${ }^{1}$.

One in 10 patients with stroke concurrently has can$\mathrm{cer}^{3}$, and the impact of their combination on survival has not been well established ${ }^{4,5}$. There are no studies specifically examining the common cardiovascular risk factors and comparing the mortality rates in patients with cancer and stroke. Stroke has been described as the first manifestation of cancer ${ }^{6-8}$, and it also has been associated with a worse prognosis ${ }^{9}$, consequently, stroke and cancer are likely to have unrecognized associations, for example, cryptogenic stroke is more frequent in cancer patients ${ }^{10,11}$. Due to the high prevalence of stroke in cancer patients and vice-versa, we aimed to analyze the stroke risk factors and outcomes in patients with cancer, which were compared with a socio-demographically similar population of stroke patients with no history of cancer, to recognize this as an added hazard element that might impact mortality rates and provide better care and prompt support.

\section{Material and methods}

This study included information from a computerized database, which was created in 2010 to collect data of patients with cancer at Instituto Nacional de Cancerología in Mexico City, a cancer referral center, who were followed up during the neuro-oncologic consultation between January 2011 and February 2018. Inclusion criteria considered patients of $\geq 18$ years with histologically confirmed diagnosis of cancer at our institute who showed evidence by magnetic resonance image (MRI) of suffering a stroke during surveillance. Exclusion criteria apply for those with a diagnosis of stroke before cancer. The data included: demographic characteristics, cancer history, stroke characteristics, follow-up duration, and time to death. Stroke type and other characteristics were obtained directly from the registry database, corroborated by MRI, and validated by a board-certified neurologist. Data on age, sex, stroke risk factors (diabetes mellitus, hypertension, hypercholesterolemia, obesity, smoking, and alcohol abuse), and mortality in this cohort were compared to those of patients with no known cancer within a previously reported cohort of stroke patients from the national registry of cerebrovascular disease. The latter cohort was reported in the RENAMEVASC study (2000 stroke patients: 1134 ischemic, 806 hemorrhagic, and 60 cerebral venous thrombosis) ${ }^{12}$ and PREMIER study (2702 ischemic stroke patients) ${ }^{13}$ The institutional ethics and investigation committee approved data acquisition (INCAN/CI/837/17) waiving the need for written consent given the characteristics of the study.

\section{Statistical analysis}

Comparisons between groups were performed to obtain risk ratios with $95 \%$ confidence intervals (Cls). $p<0.001$ was used to define statistical significance. To compare ages, Student'st-test was used after determining 
Table 1. General characteristics of patients with cancer compared to a cohort of same populations without cancer ${ }^{14}$

\begin{tabular}{|c|c|c|c|c|}
\hline & $\begin{array}{l}\text { Cancer patients } \\
n=270(\%)\end{array}$ & $\begin{array}{l}\text { Non-cancer patients } \\
n=2,000(\%)\end{array}$ & RR (95\%CI) & $\mathrm{p}$ value \\
\hline Median age (IQR), years & $58(46-68)$ & $64(49-75)$ & - & $p<0.0001$ \\
\hline $\begin{array}{l}\text { Gender } \\
\text { Female } \\
\text { Male }\end{array}$ & $\begin{array}{l}178(65.9) \\
92(34.1)\end{array}$ & $\begin{array}{l}1103(55.1) \\
897(44.9)\end{array}$ & $\begin{array}{l}1.2(1.08-1.31) \\
0.76(0.64-0.9)\end{array}$ & $\begin{array}{l}p=0.0002 \\
p=0.0018\end{array}$ \\
\hline $\begin{array}{l}\text { Stroke type } \\
\text { Ischemic } \\
\text { Hemorrhagic } \\
\text { Cerebral venous thrombosis }\end{array}$ & $\begin{array}{c}191(70.7) \\
74(27.4) \\
5(1.9)\end{array}$ & $\begin{array}{c}1,134(56.7) \\
806(40.3) \\
60(3)\end{array}$ & $\begin{array}{c}1.25(1.14-1.36) \\
0.68(0.56-0.83) \\
0.62(0.25-1.5)\end{array}$ & $\begin{array}{c}p<0.0001 \\
p=0.0002 \\
p=0.29\end{array}$ \\
\hline $\begin{array}{l}\text { Comorbidities } \\
\text { Hypertension } \\
\text { Diabetes } \\
\text { Dyslipidemia } \\
\text { Alcohol use } \\
\text { Smoking } \\
\text { Obesity } \\
\text { Cardiac ischemic disease }\end{array}$ & $\begin{array}{c}105(38.9) \\
68(25.2) \\
57(21.1) \\
65(24.1) \\
86(31.9) \\
45(16.7) \\
19(7)\end{array}$ & $\begin{array}{c}1180(59) \\
515(25.8) \\
318(15.9) \\
323(16.2) \\
476(23.8) \\
540(27) \\
180(9)\end{array}$ & $\begin{array}{c}0.66(0.56-0.77) \\
0.98(0.78-1.21) \\
1.32(1.03-1.7) \\
1.49(1.18-1.88) \\
1.34(1.1-1.6) \\
0.62(0.47-0.81) \\
0.78(0.49-1.23)\end{array}$ & $\begin{array}{c}p<0.0001 \\
p=0.84 \\
p=0.027 \\
p=0.0008 \\
p=0.0028 \\
p=0.0006 \\
p=0.28\end{array}$ \\
\hline
\end{tabular}

the mean and standard deviation using Hazen's equation ${ }^{14}$, where $p$ value is the area of the $t$ distribution with $n_{1}+n_{2}-2$ degrees of freedom, which falls outside $\pm \mathrm{t}$. All statistical analyses were performed with IBM SPSS Statistics for Windows, version 25 (IBM Corp. Armonk, N.Y., USA).

\section{Results}

A total of 270 patients with cancer and stroke were compared to a previously assembled cohort of 2000 patients with stroke and no history of cancer. The median follow-up of the cancer patients after the stroke was 13.8 months (interquartile range [IQR] of 1.3-52.4 months); after 12 months of surveillance, 11 patients were lost to follow-up. General characteristics of both cohorts are presented in table 1, with type of cancer and age subgroups details in Supplementary tables 1 and 2 (available online). Briefly, for oncology patients, gynecologic cancer was more frequently observed in ischemic stroke, while hemorrhagic and cerebral venous thrombosis were more frequent in patients with hematologic cancer; subgroup of age $<45$ years presented higher frequency $(50.8 \%)$ for hemorrhagic stroke; nonetheless, ischemic stroke leads all ages $\geq 45$ years.

Stroke risk factors that were more common in the cohort of patients without cancer were hypertension $(p<0.0001)$ and obesity $(p=0.0006)$, whereas dyslipidemia ( $p=0.027)$, alcohol abuse $(p=0.0008)$, and tobacco use ( $p=0.0028$ ) were more frequent in the cohort of patients with cancer. Analysis of the cohorts based on the stroke type revealed that the rate of hemorrhagic stroke was higher in the cohort of patients without cancer $(p=0.0002)$ and that the rate of ischemic strokes was higher in the cancer cohort ( $p<0.0001$ ); however, no difference was observed in the rate of cerebral venous thrombosis between the two groups. The analysis of the 30-day mortality rates due to ischemic stroke, according to the TOAST (Trial of Org 10172 in acute stroke treatment) ${ }^{15}$ criteria in both cohorts, presented in table 2, revealed that there was no significant difference between the two cohorts. Table 3 presents 30-day, 90-day, 6-month, and 12-month mortality rates for ischemic stroke in both cohorts. Briefly, the mortality rates at 30 and 90 days were similar between the two cohorts; however, the 6-month and 12-month mortality rates were higher in the cohort of stroke patients with cancer than in the cohort of stroke patients without cancer $(p<0.001)$.

\section{Discussion}

The comparison between 270 cancer patients who had a stroke and a cohort of 2000 stroke patients with no history of cancer from the same general population revealed that the frequency of ischemic stroke, along with the mid-term and long-term mortality rates were higher in the stroke patients with cancer. In addition, several variables associated with stroke, including alcoholism, tobacco use, and dyslipidemia were more common in the cohort of cancer patients with stroke compared to stroke patients. 
Table 2. 30-day mortality among patients with ischemic stroke with cancer $(n=191)$ or without cancer $(n=981)^{13}$

\begin{tabular}{|l|c|c|c|c|}
\hline TOAST & Cancer patients n (\%) & Non-cancer patients n (\%) & RR (95\% CI) & p value \\
\hline Large Artery Atherosclerosis & $11 / 63(17.5)$ & $8 / 84(9.5)$ & $1.83(0.78-4.3)$ & $p=0.16$ \\
\hline Lacunar & $2 / 24(8.3)$ & $5 / 213(2.5)$ & $3.55(0.73-17.3)$ & $p=0.11$ \\
\hline Cardioembolism & $10 / 42(23.8)$ & $44 / 188(23.4)$ & $1.02(0.56-1.85)$ & $p=0.96$ \\
\hline Undetermined & $8 / 27(29.6)$ & $86 / 442(19.5)$ & $1.52(0.83-2.8)$ & $p=0.18$ \\
\hline
\end{tabular}

Table 3. Mortality frequency of patients with ischemic stroke with or without cancer ${ }^{13}$

\begin{tabular}{|l|c|c|c|c|}
\hline Mortality & Cancer patients $\mathbf{n}(\%)$ & Non-cancer patients n (\%) & RR (95\% CI) & p value \\
\hline 30 days & $32 / 191(16.8)$ & $156 / 1040(15)$ & $1.11(0.79-1.6)$ & $p=0.53$ \\
\hline 90 days & $44 / 191(23)$ & $178 / 937(19)$ & $1.21(0.91-1.6)$ & $p=0.19$ \\
\hline 6 months & $71 / 191(37.2)$ & $196 / 854(23)$ & $1.62(1.3-2.02)$ & $p<0.0001$ \\
\hline 12 months & $82 / 191(42.9)$ & $238 / 821(29)$ & $1.48(1.21-1.8)$ & $p=0.00001$ \\
\hline
\end{tabular}

One study reported that the typical risk factors for stroke were less common in cancer patients ${ }^{4}$, whereas others described that hypertension and dyslipidemia were the risk factors for stroke in this patient population $^{6}$. In the current study, we found that dyslipidemia, smoking, and alcoholism were the risk factors for stroke that was more frequent in cancer patients with stroke than in stroke patients, which agrees with other studies others ${ }^{9}$. Cryptogenic stroke, observed more commonly in patients with occult cancer, with some studies reporting a frequency of $51 \%$, was previously found to be associated with a poor prognosis ${ }^{11}$. In our analyses, the etiology of the stroke could not be determined despite comprehensive evaluation in almost $30 \%$ of the cancer patients with stroke.

In the general population, the mortality rates after an ischemic stroke were reported to be approximately $15 \%, 25 \%$, and $50 \%$ at 1 month, 1 year, and 5 years, respectively ${ }^{2}$. The REVAMEVASC cohort ${ }^{12,13}$ presented lower mortality rates at 6-month and 12-month follow-up, suggesting worse mid-term and long-term prognoses for stroke patients with cancer and indicating the severe impact of stroke on survival in individuals that already have a life-threatening condition. A previous report demonstrated that patients who had the only stroke and later in life developed cancer had a worse prognosis during their clinical course ${ }^{16}$.

There are several limitations to the current study. First, a selection bias cannot be denied in this single-center study. To minimize information bias, the principal investigator (BCD) supervised all data. It must also be stated that this study did not use Chi-square or other comparative analyses since both database were independently acquired and were not paired for age, gender, or other condition. A future study would be ideal to compare these variables. Furthermore, Kaplan-Meier curves with log-rank to analyze survival are not reported, considering that access for information regarding survival or event-free survival in the RENAMEVASC database was not available. In spite of that, patients in both cohorts included in the current study share the same ethnic and demographic backgrounds, which is a strength of the study. Another major limitation was the lack of information regarding treatment and direct cause of death in many patients, which restrained our analysis.

\section{Conclusion}

Cancer and stroke are two common causes of mortality that often occur concomitantly. The frequency of ischemic stroke and the mid-term and long-term mortality rates were higher in stroke patients with cancer compared with a cohort of stroke patients with no history of cancer that shared the same sociodemographic characteristics, which should be confirmed with future, large-scale studies.

\section{Conflicts of interest}

All authors of the manuscript declare no conflicts of interest or relationship with the pharmaceutical industry. 


\section{Funding source}

This manuscript has no external funding source.

\section{Acknowledgments}

None.

\section{Ethical disclosures}

Protection of human and animal subjects. The authors declare that the procedures followed were in accordance with the regulations of the relevant clinical research ethics committee and with those of the Code of Ethics of the World Medical Association (Declaration of Helsinki).

Confidentiality of data. The authors declare that they have followed the protocols of their work center on the publication of patient data.

Right to privacy and informed consent. The authors declare that no patient data appear in this article.

\section{References}

1. GBD 2015 Mortality and Causes of Death Collaborators. Global, regional, and national life expectancy, all-cause mortality, and cause-specific mortality for 249 causes of death, 1980-2015: a systematic analysis for the global burden of disease study 2015. Lancet. 2016;388:1459-544.
2. Hankey GJ. Stroke. Lancet. 2017;389:641-54.

3. Sanossian N, Djabiras C, Mack WJ, Ovbiagele B. Trends in cancer diagnoses among inpatients hospitalized with stroke. J Stroke Cerebrovasc Dis. 2013;22:1146-50.

4. Bang OY, Seok JM, Kim SG, Hong JM, Kim HY, Lee J, et al. Ischemic stroke and cancer: stroke severely impacts cancer patients, while cancer increases the number of strokes. J Clin Neurol. 2011;7:53-9.

5. Aarnio K, Joensuu H, Haapaniemi E, Melkas S, Kaste M, Tatlisumak T, et al. Cancer in young adults with ischemic stroke. Stroke. 2015;46:1601-6.

6. Navi BB, DeAngelis LM, Segal AZ. Multifocal strokes as the presentation of occult lung cancer. J Neurooncol. 2007;85:307-9.

7. Taccone FS, Jeangette SM, Blecic SA. First-ever stroke as initial presentation of systemic cancer. J Stroke Cerebrovasc Dis. 2008;17:169-74.

8. Kwon HM, Kang BS, Yoon BW. Stroke as the first manifestation of concealed cancer. J Neurol Sci. 2007;258:80-3.

9. Navi BB, Singer S, Merkler AE, Cheng NT, Stone JB, Kamel H, et al. Cryptogenic subtype predicts reduced survival among cancer patients with ischemic stroke. Stroke. 2014;45:2292-7.

10. Schwarzbach CJ, Schaefer A, Ebert A, Held V, Bolognese M, Kablau M, et al. Stroke and cancer: the importance of cancer-associated hypercoagulation as a possible stroke etiology. Stroke. 2012;43:3029-34.

11. Navi BB, Singer S, Merkler AE, Cheng NT, Stone JB, Kamel H, et al. Recurrent thromboembolic events after ischemic stroke in patients with cancer. Neurology. 2014;83:26-33.

12. Cantú-Brito C, Ruiz-Sandoval JL, Chiquete $E$, Arauz A, León-Jiménez C, Murillo-Bonilla LM, et al. Factores de riesgo, causas y pronóstico de los tipos de enfermedad vascular cerebral en México: estudio RENAMEVASC. Rev Mex Neurocien. 2011;12:224-34.

13. Cantú-Brito C, Ruiz-Sandoval JL, Murillo-Bonilla LM, Chiquete E, León-Jiménez C, Arauz A, et al. Acute care and one-year outcome of Mexican patients with first-ever acute ischemic stroke: the PREMIER study. Rev Neurol. 2010;51:641-9.

14. Hozo SP, Djulbegovic B, Hozo I. Estimating the mean and variance from the median, range, and the size of a sample. BMC Med Res Methodol. 2005;5:13.

15. Adams HP Jr., Bendixen BH, Kappelle LJ, Biller J, Love BB, Gordon DL, et al. Classification of subtype of acute ischemic stroke. Definitions for use in a multicenter clinical trial. TOAST. Trial of org 10172 in acute stroke treatment. Stroke. 1993;24:35-41.

16. Qureshi Al, Malik AA, Saeed O, Adil MM, Rodriguez GJ, Suri MF, et al. Incident cancer in a cohort of 3,247 cancer diagnosis free ischemic stroke patients. Cerebrovasc Dis. 2015;39:262-8. 


\section{Supplementary Table}

Supplementary Table 1. Type of stroke (ischemic [ $n=191]$, hemorrhagic $[n=74]$, cerebral venous thrombosis $[n=5]$ ) presented according to the primary type of cancer $(n=270)$

\begin{tabular}{|l|c|c|c|c|}
\hline Type of cancer & $\mathbf{n}(\%)$ & Ischemic (\%) & Hemorrhagic (\%) & Cerebral Venous Thrombosis (\%) \\
\hline Gynecologic & $104(38.5)$ & $83(43.5)$ & $20(27)$ & $1(20)$ \\
\hline Hematologic & $50(18.5)$ & $26(13.6)$ & $21(28.4)$ & $3(60)$ \\
\hline Head and neck & $28(10.4)$ & $21(11)$ & $7(9.5)$ & 0 \\
\hline Lung & $21(7.8)$ & $18(9.4)$ & $3(4.1)$ & 0 \\
\hline Gastrointestinal & $22(8.1)$ & $15(7.9)$ & $7(9.5)$ & $1(20)$ \\
\hline Urologic & $30(11.1)$ & $16(8.4)$ & $13(17.6)$ & 0 \\
\hline Soft tissue and skin & $14(5.2)$ & $11(5.8)$ & $3(4.1)$ & 0 \\
\hline Unknown & $1(0.4)$ & $1(0.5)$ & 0 & 0 \\
\hline
\end{tabular}

Supplementary Table 2. Type of stroke (ischemic [ $n=191]$, hemorrhagic $[n=74]$, cerebral venous thrombosis $[n=5]$ ) presented according to group age $(n=270)$

\begin{tabular}{|l|c|c|c|c|}
\hline Group age & $\mathbf{n}(\%)$ & Ischemic (\%) & Hemorrhagic (\%) & Cerebral venous thrombosis (\%) \\
\hline$<45$ years & $59(21.9)$ & $25(42.4)$ & $30(50.8)$ & $4(6.8)$ \\
\hline $45-49$ years & $90(33.3)$ & $69(76.7)$ & $20(22.2)$ & $1(1)$ \\
\hline $60-74$ years & $93(34.4)$ & $73(78.5)$ & $20(21.5)$ & 0 \\
\hline$\geq 75$ years & $28(1.4)$ & $24(85.7)$ & $4(14.3)$ & 0 \\
\hline
\end{tabular}

